\title{
Article
}

\section{Prevalence and Clinicopathological Characteristics of Moderate and High-Penetrance Genes in Non-BRCA1/2 Breast Cancer High-Risk Spanish Families}

\author{
Maria Fonfria ${ }^{1}$, Inmaculada de Juan Jiménez ${ }^{2, *}$, Isabel Tena ${ }^{1}$, Isabel Chirivella ${ }^{3}$, Paula Richart-Aznar ${ }^{4}$, \\ Angel Segura ${ }^{4} \mathbb{D}$, Ana Beatriz Sánchez-Heras ${ }^{5}$ and Eduardo Martinez-Dueñas ${ }^{1}$ \\ 1 Cancer Genetic Counseling Unit, Medical Oncology Department, Castellon Provincial Hospital, \\ 12002 Castellon, Spain; mfonfria@uji.es (M.F.); tenagarcia.Isabel@gmail.com (I.T.); \\ eduardo.martinez@hospitalprovincial.es (E.M.-D.) \\ 2 Molecular Biology Unit, Service of Clinical Analysis, La Fe University Hospital, 46026 Valencia, Spain \\ 3 Medical Oncology Department, INCLIVA Biomedical Research Institute, University of Valencia, \\ 46001 Valencia, Spain; chirivella_isa@gva.es \\ 4 Cancer Genetic Counseling Unit, Medical Oncology Department, La Fe University Hospital, \\ 46026 Valencia, Spain; paularichart@gmail.com (P.R.-A.); segura_ang@gva.es (A.S.) \\ 5 Cancer Genetic Counseling Unit, Medical Oncology Department, Elche University Hospital, \\ 03203 Elche, Spain; sanchez_ana@gva.es \\ * Correspondence: dejuan_inm@gva.es; Tel.: +34-961244587
}

Citation: Fonfria, M.; de Juan Jiménez, I.; Tena, I.; Chirivella, I.; Richart-Aznar, P.; Segura, A.; Sánchez-Heras, A.B.;

Martinez-Dueñas, E. Prevalence and Clinicopathological Characteristics of Moderate and High-Penetrance Genes in Non-BRCA1/2 Breast Cancer High-Risk Spanish Families. J. Pers. Med. 2021, 11, 548. https:// doi.org/10.3390/jpm11060548

Academic Editor: Joanne Dickinson

Received: 26 April 2021

Accepted: 10 June 2021

Published: 12 June 2021

Publisher's Note: MDPI stays neutral with regard to jurisdictional claims in published maps and institutional affiliations.

Copyright: (c) 2021 by the authors. Licensee MDPI, Basel, Switzerland. This article is an open access article distributed under the terms and conditions of the Creative Commons Attribution (CC BY) license (https:/ / creativecommons.org/licenses/by/ $4.0 /)$.

\begin{abstract}
Background: Over the last decade, genetic counseling clinics have moved from singlegene sequencing to multigene panel sequencing. Multiple genes related to a moderate risk of breast cancer (BC) have emerged, although many questions remain regarding the risks and clinical features associated with these genes. (2) Methods: Ninety-six BC index cases (ICs) with high-risk features for hereditary breast and ovarian cancer (HBOC) and with a previous uninformative result for $B R C A 1 / 2$ were tested with a panel of 41 genes associated with BC risk. The frequency of pathogenic variants (PVs) was related to the clinical characteristics of BC. (3) Results: We detected a PV rate of $13.5 \%$ (excluding two cases each of BRCA1 and MUTYH). Among the 95 assessed cases, 17 PVs were identified in 16 ICs, as follows: BRCA1 $(n=2)$, CHEK2 $(n=3), \operatorname{ATM}(n=5), \operatorname{MUTYH}(n=2), \operatorname{TP53}$ $(n=2)$, BRIP1 $(n=1)$, CASP8 $(n=1)$, and MSH2 $(n=1)$. We also identified a novel loss-of-function variant in $C A S P 8$, a candidate gene for increased $B C$ risk. There was no evidence that the clinical characteristics of BC might be related to a higher chance of identifying a PV. (4) Conclusions: In our cohort, which was enriched with families with a high number of BC cases, a high proportion of mutations in ATM and CHEK2 were identified. The clinical characteristics of BC associated with moderate-risk genes were different from those related to $B R C A 1 / 2$ genes.
\end{abstract}

Keywords: hereditary breast and ovarian cancer; germline testing; BRCA1 or BRCA2 negative; moderate penetrance genes; next-generation sequencing

\section{Introduction}

Breast cancer $(\mathrm{BC})$ is the most frequent cancer type in women and one of the main causes of female mortality. Each year, 2.08 million new cases are diagnosed and there are approximately 626,679 deaths secondary to BC worldwide [1]. In Spain, there are 25,215 new cases of BC per year, making BC the leading cause of cancer-related mortality in women $(15.5 \%$ of deaths caused by cancer). It is estimated that $5-10 \%$ of BC cases have hereditary causes, but among individuals seeking clinical evaluation for hereditary $B C$, pathogenic variants (PVs) or suspected PVs were only found in BRCA1 and BRCA2 (BRCA1/2) in 9-29\% of cases [2]. In addition, rare germline variants in known high-risk genes such as TP53, CDH1, STK11, and PTEN predispose to well-defined hereditary cancer syndromes in which BC also develops [3]. 
In the last decade, advances in sequencing methods have revealed a marked heterogeneity in the loci related to hereditary breast and ovarian cancer (HBOC), with more than 25 genes emerging, most of which are involved in maintenance and repair genome pathways connected with $B R C A 1 / 2$ [4]. These moderate-risk genes confer a two to five-fold higher risk of $\mathrm{BC}$, have a variable penetrance, and their expression can be modified by many factors such as other genes, family history, and environmental influences [5]. Several publications in recent years have found that the most frequently altered genes are CHEK2, $A T M$, and PALB2. While the role of BRCA1/2 in HBOC is well established, the role of new emerging factors in the development of HBOC has not yet been fully defined, nor has the role they can play in the tumor phenotype. Recent studies have reported that in families with suspected HBOC, almost $50 \%$ of the PVs detected were identified in genes other than $B R C A 1 / 2$ [6]. Most notable was that no gene was detected in $64-86.5 \%$ of women who were clinically evaluated for hereditary BC [7]. In addition, it has been suggested that tumors secondary to mutations in gene pathways similar to $B R C A 1 / 2$ could present an increased sensitivity to PARP inhibitors [4].

The identification of new genetic variants using gene panels offers new possibilities for patients and families with suspected HBOC, but also offers new challenges for clinical management and genetic counseling. Multiple commercial panels have been developed, with each one covering a variable number of high- or moderate-risk genes with single nucleotide polymorphisms (SNPs), alongside candidate genes whose risk is not yet clearly defined in current guidelines [5]. Considering these factors, several publications have warned about the lack of regulation of these panels and the multiple clinical and ethical considerations associated with their use $[5,8,9]$. To establish the clinical utility of these panels, we must first understand the prevalence, penetrance, and phenotypes of $B C$ predisposing mutations other than $B R C A 1 / 2$ in order to make the best use of these data in genetic clinical services. The use of multi-gene panels in research protocols allows researchers to explore the epidemiology and causal role of these genes and to assess which ones should be offered in the context of genetic counseling.

In this current work, we analyzed a population with a high-risk of $\mathrm{HBOC}$ and without $B R C A 1 / 2$ mutations to determine the prevalence and penetration of mutations in other genes predisposing these patients to BC. We also analyzed the tumor phenotype present in mutations other than $B R C A 1 / 2$ in order to obtain prognostic and clinical-pathological information.

\section{Materials and Methods}

\subsection{Patient Selection}

The study participants were retrospectively selected from a population of $\mathrm{BC}$ patients who met the criteria for high-risk HBOC provided by the Comunidad Valenciana Cancer Plan in Spain. These patients had been previously assessed in genetic cancer clinics at different hospitals in the Comunidad Valenciana and had uninformative test results for their BRCA1/2 status. The high-risk criteria for BC used to refer patients to genetic clinics between 2005 and 2016 were used for patient selection, although we prioritized families with a larger number of BC cases. These criteria were (1) families with three or more cases of breast or ovarian cancer (OC) among their first or second-degree relatives; (2) two first-degree relatives with $\mathrm{BC}$ diagnosed before the age of 50 years; (3) two first-degree relatives with $\mathrm{BC}$, one of them bilateral $\mathrm{BC}$ and the other diagnosed before the age of 40 years, and (4) two first-degree relatives with one case of $\mathrm{BC}$ and one case of $\mathrm{OC}$. We excluded families with just one case of $\mathrm{BC}$ at a young age.

The demographic, clinical, and familial histories were collected from genealogical trees and medical records. Informed consent was obtained from all subjects involved in this study. Positive results for any variants with clinical implications were reported to the patient. However, variants with unknown significance (VUS) and alterations in genes with no established clinical management were not reported to patients. This study was approved by the Ethical Review Board at the Provincial Hospital of Castellon. 


\subsection{DNA Extraction}

A total of $96 \mathrm{BC}$ index patients with a high risk of $\mathrm{BC}$ were selected retrospectively. We extracted DNA from peripheral blood lymphocytes sample for their BRCA1/2 study and the excess was stored in the Health Care Biobank. The study was performed in genomic DNA extracted from $500 \mu \mathrm{L}$ of whole blood using the MagNA Pure LC DNA Isolation Kit, large volume (Roche, Mannheim, Germany) automated in the MagNA Pure LC System (Roche), according to the manufacturer's protocol.

\subsection{Next Generation Sequencing}

We included 11,820 XT target capture probes (Agilent, Santa Clara, CA, USA) on an array (size $=251,139 \mathrm{kbp}$ ) for the target enrichment of the entire gene coding regions and all the flanking non-coding regions for the following selected genes: ATM, BARD1, BLM, BRCA1, BRCA2, BRIP1, CASP8, CDH1, CDK4, CDKN2A, CHEK2, FANCA, FANCC, FANCD2, FANCE, FANCF, FANCG, FANCM, FAM175A, KRAS, MAP3K1, MEN1, MLH1, MSH2, MSH6, MRE11A, MUTYH, NBN, NF1, PALB2, PTCH1, PTEN, RAD50, RAD51B, RAD51C, RAD51D, REQCL, STK11, TGFB1, TP53, and XRCC2. The capture was performed automatically using a Bravo Robot according to the manufacturer's instructions.

The enriched libraries were clonally amplified on a solid substrate for next-generation sequencing (NGS) using Illumina V3 chemistry on a MiSeq System (Illumina, San Diego, CA, USA) to an average coverage of $300 \times$ with $2 \times 150$ paired-reads and a minimum coverage of $25 \times$ (with a variant allele frequency cutoff of $20.0 \%$ ) for each targeted position. Reads were aligned to the hg19/GRCh37 reference human genome build using Alissa Interpret (Agilent technologies, Santa Clara, CA, USA). A minimum quality threshold of Q20, which translates into a sequencing accuracy of $>90 \%$ for all called bases, was applied. All the clinically relevant variants detected were confirmed by Sanger sequencing.

\subsection{Variant Classifications}

We consulted databases including VarSome, ClinVar, and UMD to classify the variants according to a five-tier system (deleterious: class 5; likely deleterious: class 4; VUS: class 3; likely benign: class 2; and benign: class 1 ) following recommendations proposed by the American College of Medical Genetics and Genomics (ACMG). We used the nomenclature approved by the HGVS.

\subsection{Statistical Analysis}

The prevalence of the mutations detected and patient characteristics were reported with descriptive statistics. The demographic, clinical, and pathological characteristics were compared using $\chi^{2}$ tests for categorical variables and Student's $t$-tests or analysis of variance for continuous variables. The odds ratio $(\mathrm{OR})$ was compared between the different groups for each clinical factor using Fisher exact tests. Quantitative variables without a normal distribution were tested with the non-parametric alternative (Mann-Whitney $\mathrm{U}$ or Wilcoxon tests). $p$-values $<0.05$ were considered significant in every case.

\section{Results}

\subsection{Characteristics of the Study Population}

We selected 96 BC index patients (92 women and 4 men) from Spanish families with a high risk of $B C$ from four departmental hospitals. As shown in Figure 1, our study population was enriched with patients with a high number of BC cases in their family history (median number $=3$, range $=1-10$ ). In addition, $16 \%$ of the families reported cases of OC, $16 \%$ had prostate cancer cases, $6 \%$ had pancreatic cancer cases, and $8 \%$ had colon cancer cases. 


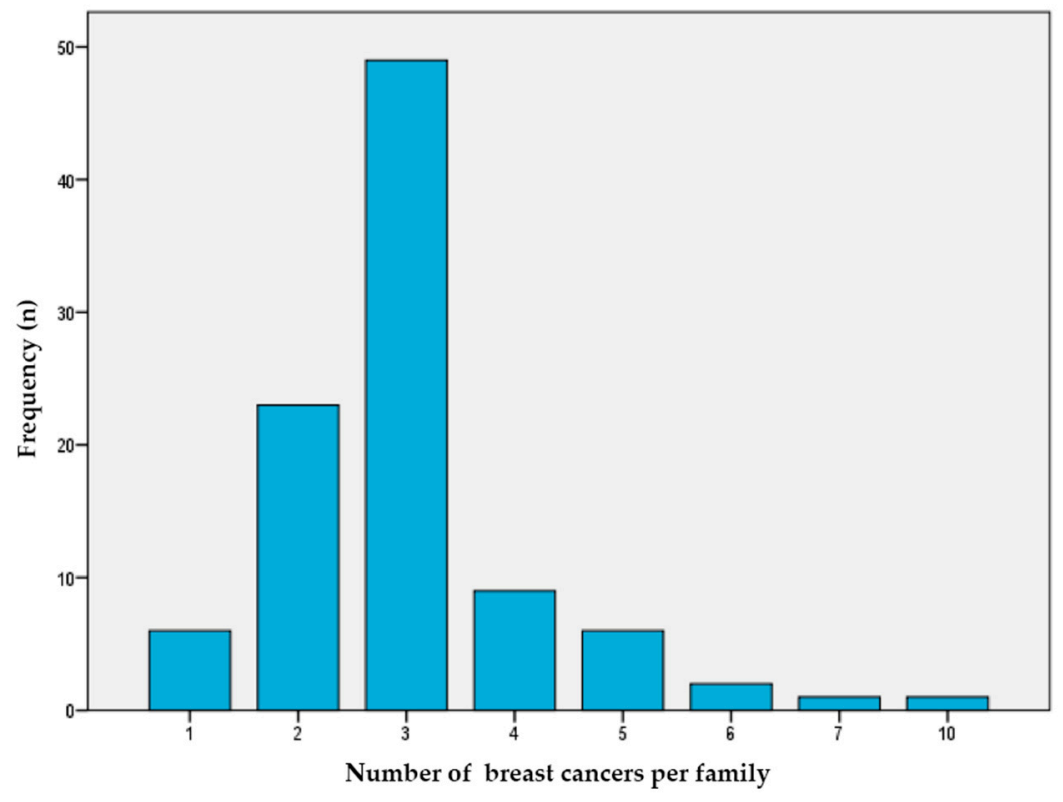

Figure 1. Number of breast cancer cases per family. This figure shows the number of breast cancer per family ( $X$ axis) that each index case in the study presents ( $Y$ axis).

The median age at BC diagnosis was 46.0 years (range $23-73)$, with most IC (75\%) having been diagnosed before 50 years of age, $8 \%$ of which were patients aged $<30$ years. In addition, $18 \%$ of these patients had had bilateral BC; $75 \%$ of the tumors were hormone receptor-positive and $16 \%$ had a HER2 amplification. Information regarding HER2 was unavailable in $18 \%$ of cases, mainly when patients had been diagnosed before HER 2 was routinely determined (before the year 2000). The patient characteristics are summarized in Table 1.

Table 1. Characteristics of study population.

\begin{tabular}{|c|c|c|c|}
\hline & All & With Mutation ${ }^{1}$ & Without Mutation \\
\hline Total patients $(n)$ & 95 & 14 & 81 \\
\hline \multicolumn{4}{|l|}{ Sex } \\
\hline Female & $91(95.7 \%)$ & $13(92.8 \%)$ & $78(96.2 \%)$ \\
\hline Male & $4(4.2 \%)$ & $1(7.14 \%)$ & $3(3.7 \%)$ \\
\hline Median age at diagnosis (range) & $46(23-73)$ & $45(28-66)$ & $46(23-73)$ \\
\hline \multicolumn{4}{|l|}{ Age at diagnosis } \\
\hline$<30$ & $8(8.4 \%)$ & $1(7.1 \%)$ & $7(8.6 \%)$ \\
\hline $30-40$ & $22(23.1 \%)$ & $4(28.5 \%)$ & $18(22.2 \%)$ \\
\hline $41-50$ & $43(45.2 \%)$ & $6(42.8 \%)$ & $37(45.6 \%)$ \\
\hline $51-60$ & $17(17.8 \%)$ & $1(7.1 \%)$ & $16(19.7 \%)$ \\
\hline $61-70$ & $5(5.2 \%)$ & $1(7.1 \%)$ & $4(4.9 \%)$ \\
\hline$>70$ & $1(1.0 \%)$ & 0 & $1(1.2 \%)$ \\
\hline \multicolumn{4}{|l|}{ T stage } \\
\hline Tis & $9(9.4 \%)$ & 0 & $9(11.1 \%)$ \\
\hline $\mathrm{T} 1$ & $43(45.2 \%)$ & $4(28.1 \%)$ & $39(48.1 \%)$ \\
\hline $\mathrm{T} 2$ & $31(32.6 \%)$ & $4(28.1 \%)$ & $27(33.3 \%)$ \\
\hline T3 & $8(8.4 \%)$ & $2(14.2 \%)$ & $5(6.1 \%)$ \\
\hline $\mathrm{T} 4$ & $2(2.1 \%)$ & $1(7.1 \%)$ & $1(1.2 \%)$ \\
\hline \multicolumn{4}{|l|}{ N stage } \\
\hline No & $56(58.9 \%)$ & $4(28.5 \%)$ & $52(64.1 \%)$ \\
\hline N1 & $30(31.5 \%)$ & $5(35.7 \%)$ & $25(30.8 \%)$ \\
\hline N2-N3 & $8(8.4 \%)$ & $3(21.4 \%)$ & $5(6.1 \%)$ \\
\hline \multicolumn{4}{|l|}{ Grade } \\
\hline 1 & $22(23.1 \%)$ & $5(35.7 \%)$ & $17(20.9 \%)$ \\
\hline 2 & $41(43.1 \%)$ & $6(42.8 \%)$ & $35(43.2 \%)$ \\
\hline
\end{tabular}


Table 1. Cont.

\begin{tabular}{|c|c|c|c|}
\hline & All & With Mutation ${ }^{1}$ & Without Mutation \\
\hline 3 & $21(22.1 \%)$ & $1(7.1 \%)$ & $20(24.6 \%)$ \\
\hline Unknown & $13(13.6 \%)$ & $2(14.2 \%)$ & $11(13.5 \%)$ \\
\hline \multicolumn{4}{|l|}{ Hormonal receptor status } \\
\hline Positive & $74(77.8 \%)$ & $11(78.5 \%)$ & $63(77.7 \%)$ \\
\hline Negative & $14(14.7 \%)$ & $2(14.2 \%)$ & $12(14.8 \%)$ \\
\hline Unknown & $8(8.4 \%)$ & $1(7.1 \%)$ & $7(8.6 \%)$ \\
\hline \multicolumn{4}{|l|}{ Estrogen receptor status } \\
\hline Positive & $71(73.6 \%)$ & $9(64.2 \%)$ & $61(75.3 \%)$ \\
\hline Negative & $17(17.8 \%)$ & $4(28.5 \%)$ & $14(17.2 \%)$ \\
\hline Unknown & $7(8.4 \%)$ & $1(7.1 \%)$ & $6(7.4 \%)$ \\
\hline \multicolumn{4}{|l|}{ Her2 status } \\
\hline Positive & $16(16.8 \%)$ & $2(14.2 \%)$ & $14(17.2 \%)$ \\
\hline Negative & $63(66.3 \%)$ & $10(71.4 \%)$ & $53(65.4 \%)$ \\
\hline Unknown & $18(18.9 \%)$ & $2(14.2 \%)$ & $16(19.7 \%)$ \\
\hline \multicolumn{4}{|l|}{ Immunophenotype } \\
\hline Luminal A & $35(36.8 \%)$ & $6(42.8 \%)$ & $29(35.8 \%)$ \\
\hline Luminal B & $22(23.1 \%)$ & $3(21.4 \%)$ & $19(23.4 \%)$ \\
\hline Triple negative & $7(7.3 \%)$ & $1(7.1 \%)$ & $6(7.4 \%)$ \\
\hline Her2 + Hormonal Receptor - & $5(5.2 \%)$ & $1(7.1 \%)$ & $4(12.3 \%)$ \\
\hline Triple positive & $11(11.5 \%)$ & $1(7.1 \%)$ & $10(12.3 \%)$ \\
\hline Unknown & $17(17.8 \%)$ & $2(14.2 \%)$ & $15(18.5 \%)$ \\
\hline Bilateral breast cancer & $18(18.9 \%)$ & $3(21.4 \%)$ & $15(18.5 \%)$ \\
\hline \multicolumn{4}{|l|}{ Family history of cancer } \\
\hline Breast & $95(100 \%)$ & $14(100 \%)$ & $81(100 \%)$ \\
\hline Melanoma & $2(2.1 \%)$ & 0 & $2(2.4 \%)$ \\
\hline Ovarian & $17(17.8 \%)$ & $2(14.2 \%)$ & $15(17.8 \%)$ \\
\hline Prostate & $17(17.8 \%)$ & $2(14.2 \%)$ & $15(17.8 \%)$ \\
\hline Colorectal & $9(9.4 \%)$ & $3(21.4 \%)$ & $6(7.4 \%)$ \\
\hline Pancreatic & $5(5.2 \%)$ & $1(7.1 \%)$ & $4(4.7 \%)$ \\
\hline Others & $13(13.6 \%)$ & $3(21.4 \%)$ & $10(12.3 \%)$ \\
\hline
\end{tabular}

${ }^{1}$ Two ICs with monoallelic MUTYH mutation have been included in the "no mutation subgroup" because of the recessive inheritance of this mutation.

\subsection{Next-Generation Sequencing Quality}

Among the 96 BC ICs selected for analysis, 95 passed the sequencing quality filters for further data analysis. The average and median read depth in analyzable target regions was $65 \mathrm{x}$ (range $=50-115$ ); the mean percentage of analyzable target regions covered by at least 50 reads was $98.8 \%$, with $95.58 \%$ being covered at least by 100 reads (Supplementary Data, Figures S1 and S2). All the variants were detected in a deep $>25 \times($ range $=30-100 \times)$ and PV were confirmed by Sanger sequencing.

\subsection{Frequency of Deleterious Mutations}

Among the 95 cases studied, 17 PVs were identified in 16 ICs as follows: BRCA1 $(n=2)$, CHEK2 ( $n=3$, one frameshift, and two stop codon), ATM $(n=5$, two splicing, one frameshift, and two stop codon), MUTYH $(n=2)$, TP53 ( $n=2$, two missense), BRIP1 $(n=1)$, CASP8 $(n=1)$ and MSH2 $(n=1)$. We identified one woman with two PVs, one each in the ATM and CHEK2 genes. We also found 26 VUS in 22 ICs (22.9\%). VUS are listed in Supplementary Materials, Table S1. Indeed, five of the ICs harbored two variants (one patient with two PVs, one patient with a PV and a VUS and three patients with two VUS).

In addition, we found two PVs in the BRCA1 gene. In one patient, the c.5324T > G (p.Met1775Arg) variant had been previously classified as a VUS when she had first been evaluated at the genetic cancer clinic, but this VUS has since been reclassified as a PV. The PV detected in the other patient was BRCA1 NM_007294.3 c.5152 + 5G > A and had remained undetected in her first study. According with these new classifications or 
detections, we contacted these two women and offered them updated recommendations and familial screening. We also detected two monoallelic pathogenic mutations in MUTYH.

Frequencies of PVs and VUS are summarized in Figure 2. Excluding these two BRCA1 mutations and the two monoallelic MUTYH mutations, our PV rate in non-BRCA1/2 genes was $13.5 \%$. The most prevalent variants detected were in ATM (5.2\%) and CHEK2 (3.1\%), with mutations in these two genes accounting for $47 \%$ of the all the PVs detected. The remaining PVs were in TP53 (2.08\%), BRIP1 (1.04\%), MSH2 (1.04\%), and CASP8 (1.04\%), as described in Table 2.

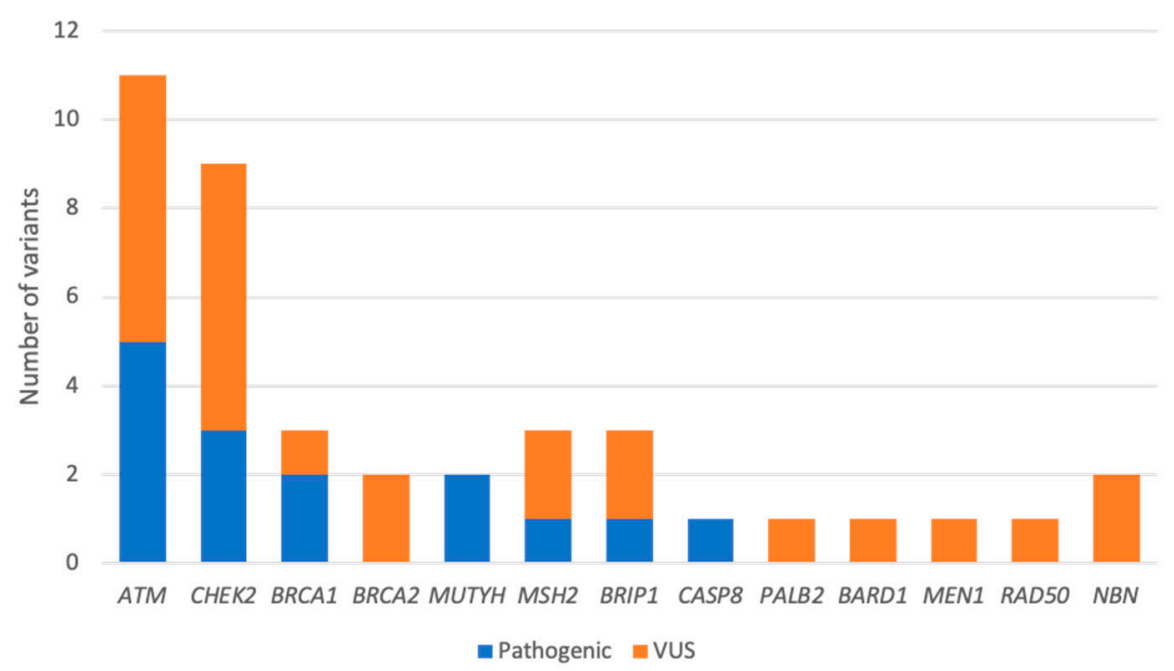

Figure 2. Distribution of germline variants detected by an NGS panel of 41 genes. Variants are classified as pathogenic (Class 4 or 5) or VUS (Class 3).

Furthermore, we found two unrelated index BC cases with the same PV (NM_00051.4:c.2921 + 1G > A) in ATM (rs587781558). One IC harbored the CHEK2 variant (NM_007194.4:c.1036C > T) (rs201206424), a missense variant classified as a VUS by ClinVar and as likely pathogenic by VarSome. This sequence replaces arginine with cysteine at codon 346 of the CHEK2 protein ( $p$.Arg346Cys) and has been reported to affect CHEK2 protein function [10]. In addition it has been observed in individuals affected with BC [11]. However, the available evidence is currently insufficient to determine the role of this variant in disease and therefore, it was classified as a VUS (or C:3).

\subsection{Clinical Characteristics in Cases with Pathogenic Variants}

In terms of different age ranges, PVs were present in $13.6 \%$ of individuals aged under 45 years $(n=44)$ and in $11.8 \%$ of those aged over 45 years $\left(n=50 ; \chi^{2}=0.075, p=0.784\right.$ after excluding cases with a PV in BRCA1/2 or MUTYH). The median age was 45 years (range 28-66) among patients with a PV and 46 years (range 23-73) in those with no mutation, with no significant differences observed between these groups. In addition, the number of $\mathrm{BC}$ cases in the family or the presence of bilateral BC was not a predictor for the detection of a PV. Moreover, a correlation analysis using Fisher tests found no link between the clinical factors we evaluated and an increased risk of detecting a PV (Table 3). 
Table 2. Pathogenic variants in the study cohort.

\begin{tabular}{|c|c|c|c|c|c|c|c|c|c|c|c|c|c|c|}
\hline \multicolumn{9}{|c|}{ Gene Variants } & \multicolumn{3}{|c|}{ Personal History } & \multicolumn{3}{|c|}{ Family History } \\
\hline $\begin{array}{l}\text { Study } \\
\text { ID }\end{array}$ & Gene & $\begin{array}{l}\text { Variant } \\
\text { Type }\end{array}$ & Class $^{1}$ & HGVS Coding & HGVS Protein & Transcripts & rsID & 2nd Variant & $\begin{array}{l}\text { BC } \\
\text { Age }\end{array}$ & $\begin{array}{l}\text { Subtype } \\
\text { (ER/PR/HER2) }\end{array}$ & $\begin{array}{l}\text { Bilateral } \\
\text { BC }\end{array}$ & $\begin{array}{l}\text { No. } \\
\text { Cancers }\end{array}$ & $\begin{array}{l}\text { No. } \\
\text { BCs }\end{array}$ & $\begin{array}{l}\text { No. } \\
\text { OCs }\end{array}$ \\
\hline 35022 & $B R C A 1$ & Splicing & 5 & c. $5152+5 \mathrm{G}>\mathrm{A}$ & - & NM_007294.3 & rs80358165 & - & 45 & $-/+/-$ & No & 2 & 2 & 0 \\
\hline 30983 & $B R C A 1$ & Missense & 4 & c. $5324 \mathrm{~T}>\mathrm{G}$ & p.Met1775Arg & NM_07300.4 & rs41293463 & - & 31 & $-1-1-$ & Yes & 1 & 1 & 0 \\
\hline 24247 & ATM & Stop codon & 5 & c. $2413 C>T$ & p.Arg805Ter & NM_000051.4 & rs780619951 & - & 34 & $+/+/-$ & Yes & 3 & 2 & 0 \\
\hline 45434 & ATM & Splicing & 5 & c. $2921+1 G>A$ & - & NM_000051.4 & rs587781558 & - & 42 & $+/+/-$ & No & 3 & 3 & 0 \\
\hline 36845 & ATM & Splicing & 5 & c. $2921+1 G>A$ & - & NM_000051.4 & rs587781558 & - & 45 & $+/+/-$ & No & 4 & 2 & 1 \\
\hline 26672 & ATM & Frameshift & 5 & c.43delC & p.Leu15Terfs & NM_000051.4 & rs771887195 & - & 48 & $+/+/-$ & No & 2 & 2 & 0 \\
\hline 47150 & ATM & $\begin{array}{l}\text { Stop } \\
\text { Codon }\end{array}$ & 5 & c. $4507 \mathrm{C}>\mathrm{T}$ & p.Gln1503Ter & NM_000051.4 & rs1131691164 & $\begin{array}{l}\text { CHEK2 c.1555C > T } \\
\text { (p.Arg519Ter)Class } 5\end{array}$ & 48 & $+/+/-$ & No & 3 & 2 & 1 \\
\hline 60766 & CHEK2 & $\begin{array}{l}\text { Stop } \\
\text { Codon }\end{array}$ & 5 & c. $279 \mathrm{G}>\mathrm{A}$ & p.Trp93Ter & NM_007194.4 & rs587782070 & - & 66 & $+/+/-$ & Yes & 10 & 10 & 0 \\
\hline 36497 & CHEK2 & Frameshift & 5 & c.591delA & p.Val198Phefs & NM_007194.4 & rs587782245 & - & 37 & $+/+/+$ & No & 3 & 2 & 0 \\
\hline 55930 & TP53 & Missense & 5 & c. $743 \mathrm{G}>\mathrm{A}$ & p.Arg248Gln & NM_000546.6 & rs11540652 & - & 28 & $-/-/+$ & No & 3 & 2 & 0 \\
\hline 18358 & TP53 & Missense & 5 & c. $638 \mathrm{G}>\mathrm{A}$ & p.Arg213Gln & NM_000546.6 & rs587778720 & - & 32 & $-/+/ ?$ & No & 6 & 3 & 0 \\
\hline 61221 & BRIP1 & Splicing & 5 & c. $508-2 \mathrm{~A}>\mathrm{T}$ & - & NM_032043.2 & rs876659707 & - & 62 & $+/+/-$ & No & 3 & 1 & 0 \\
\hline 36984 & MUTYH & Missense & 5 & c. $1187 \mathrm{G}>\mathrm{A}$ & p.Gly396Asp & NM_001048174.2 & rs36053993 & - & 50 & $+/+/-$ & No & 3 & 3 & 0 \\
\hline 43701 & MUTYH & Missense & 5 & c. $1187 \mathrm{G}>\mathrm{A}$ & p.Gly396Asp & NM_001048174.2 & rs36053993 & - & 51 & $+/-/-$ & No & 4 & 3 & 0 \\
\hline 38266 & CASP8 & Frameshift & 4 & c.331delG & p.Ala111Leufs*22 & NM_01228.4 & rs776712453 & $\begin{array}{l}\text { NBN c.1238A > G } \\
\text { (p.Asn413Ser) Class } 3\end{array}$ & 57 & $+/+/-$ & No & 7 & 3 & 0 \\
\hline
\end{tabular}

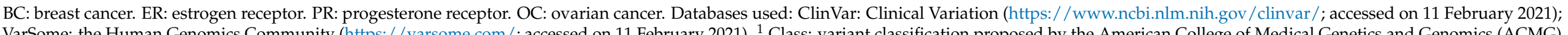

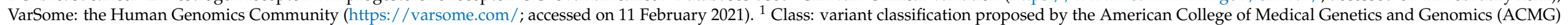
(deleterious: class 5; likely deleterious: class 4; VUS: class 3; likely benign: class 2; and benign: class 1). 
Table 3. Comparison of the odds ratio (OR) of pathogenic variants (PVs) in different groups for each clinical factor using Fisher exact tests.

\begin{tabular}{|c|c|c|c|c|}
\hline Clinical Factors & Level & PV Ratio & OR $(95 \%$ CI $)$ & $p$-Value \\
\hline \multirow{2}{*}{ Age } & $\leq 45$ & $17.78 \%(8 / 45)$ & 1.32 & \multirow{2}{*}{0.77927} \\
\hline & $>45$ & $14.00 \%(7 / 50)$ & $(0.38,4.74)$ & \\
\hline \multirow[b]{2}{*}{ Bilateral involvement } & No & $15.79 \%(12 / 76)$ & 0.94 & \multirow[b]{2}{*}{1} \\
\hline & Yes & $16.67 \%(3 / 18)$ & $(0.21,5.82)$ & \\
\hline \multirow{2}{*}{ Luminal } & No & $15.00 \%(6 / 40)$ & 0.90 & \multirow{2}{*}{1} \\
\hline & Yes & $16.36 \%(9 / 55)$ & $(0.24,3.16)$ & \\
\hline \multirow{2}{*}{ Her2 positive } & No & $19.05 \%(12 / 63)$ & 1.64 & \multirow{2}{*}{0.72285} \\
\hline & Yes & $12.50 \%(2 / 16)$ & $(0.31,16.78)$ & \\
\hline \multirow{2}{*}{ Triple negative } & No & $15.91 \%(14 / 88)$ & 1.13 & \multirow{2}{*}{1} \\
\hline & Yes & $14.29 \%(1 / 7)$ & $(0.12,55.90)$ & \\
\hline \multirow{2}{*}{ Family ovarian cancer } & No & $16.25 \%(13 / 80)$ & 1.26 & \multirow[b]{2}{*}{1} \\
\hline & Yes & $13.33 \%(2 / 15)$ & $(0.24,12.80)$ & \\
\hline \multirow{5}{*}{ Stage } & 0 & $0.00 \%(0 / 10)$ & & \multirow{5}{*}{0.12418} \\
\hline & I & $13.79 \%(4 / 29)$ & & \\
\hline & II & $13.16 \%(5 / 38)$ & & \\
\hline & III & $37.5 \%(6 / 16)$ & & \\
\hline & IV & $0.00 \%(0 / 1)$ & & \\
\hline
\end{tabular}

Note: the odds ratios were compared using Fisher exact tests.

After excluding patients with PVs in BRCA1 and MUTYH, we identified a pathogenic mutation in 9 of the 67 patients who were hormone receptor-positive (13.4\%). Information regarding HER2 status was available for a subgroup of 80 patients; we detected a mutation in two $(12.5 \%)$ of the sixteen patients with a HER2 amplification. We were only able to confirm seven cases with triple negative $\mathrm{BC}$, among which a mutation in BRCA1 and no pathogenic mutation in non-BRCA genes were detected (Table 4). All the cases of BC with $C H E K 2$ mutations were hormone receptor-positive and one harbored an amplified HER2, but we did not identify any cases with the founder mutation c.1100delC. Of note, the families of these ICs had experienced a high number of BC cases (between 3 and 10). In addition, some authors have suggested an association with colon cancer for CHEK2 mutations [12]. One of our ICs had metachronous breast and colon cancer at a young age. No other cases of colon cancer were described in the other families of patients with the CHEK2 mutation.

Table 4. Deleterious mutations by breast cancer (BC) subtype.

\begin{tabular}{|c|c|c|c|c|c|c|}
\hline \multirow[t]{2}{*}{ Genes } & \multicolumn{2}{|c|}{$\begin{array}{l}\text { Patients with Luminal BC } \\
(n=57)\end{array}$} & \multicolumn{2}{|c|}{$\begin{array}{l}\text { Patients with HER2 } \\
\text { Positive BC } \\
(n=16)\end{array}$} & \multicolumn{2}{|c|}{$\begin{array}{l}\text { Patients with Triple } \\
\text { Negative BC }(n=7)\end{array}$} \\
\hline & No. & $\%(95 \% \mathrm{CI})$ & No. & $\%(95 \% \mathrm{CI})$ & No. & $\%(95 \% \mathrm{CI})$ \\
\hline Any deleterious mutation & 9 & $9.5(3.5-15.3)$ & 2 & $2.1(0-4.9)$ & 1 & $1.1(0.1-3.1)$ \\
\hline \multicolumn{7}{|l|}{ Genes related to breast cancer } \\
\hline$B R C A 1$ & 1 & $1.1(0.1-3.1)$ & 0 & & 1 & $1.1(0.1-3.1)$ \\
\hline ATM & 5 & $5.3(0.7-9.7)$ & 0 & & 0 & \\
\hline CHEK2 & 3 & $3.2(0.3-6.6)$ & 1 & $1.1(0.1-3.1)$ & 0 & \\
\hline TP53 & 1 & $1.1(0.1-3.1)$ & 1 & $1.1(0.1-3.1)$ & 0 & \\
\hline \multicolumn{7}{|c|}{$\begin{array}{l}\text { Genes not clearly related to breast } \\
\text { cancer }\end{array}$} \\
\hline MSH2 & 1 & $1.1(0.1-3.1)$ & 0 & & 0 & \\
\hline BRIP1 & 1 & $1.1(0.1-3.1)$ & & & & \\
\hline Candidate genes & & & 0 & & 0 & \\
\hline CASP8 & 1 & $1.1(0.1-3.1)$ & 0 & & 0 & \\
\hline
\end{tabular}


Furthermore, ICs with mutations in ATM presented BC with hormonal receptor expression and without HER2 amplification. The average number of $B C$ cases in ATM families was lower than for CHEK2 (between two to three cases of BC per family) and one of these families had two cases of OC. Recent data have described an association between ATM and OC [13].

Two PVs were identified in TP53; the two ICs were diagnoses of BC at a notably young age (28 and 32 years) and one of them had a HER2 amplification. However, the information regarding HER2 was unavailable in the other case because the initial BC diagnosis had been made before HER2 determination was routine. We identified one pathogenic mutation in BRIP1 in a family without any reported cases of OC. Finally, we also identified a PV in $M S H 2$ in a case of a family with two or more cases of $\mathrm{BC}$ and one case of colon cancer, without meeting the Bethesda or Amsterdam criteria; in addition, this IC harbored a VUS in $R A D 50$.

\section{Discussion}

All the PVs detected in our series have been previously described as disease-causing agents (BC families, Li-Fraumeni syndrome, Lynch syndrome, or ataxia-telangiectasia) [11,14-24], except for the BRIP1 NM_032043.2:c.508-2A > T (rs876659797) and CASP8 NM_01228.4: c.331delG (rs776712453). The BRIP1 variant has not been reported previously in the literature in individuals with BRIP1-related disease [25]. The CASP8 variant is a novel variant that has been classified as likely pathogenic in VarSome but has not yet been described in ClinVar; it is a rare variant with an allele frequency of 0.000024 in GnomAD (exomes). The MUTYH monoallelic mutation rate of $2 \%$ is similar to the rate that would be expected in the general population [26].

In our series, the PV detection rate was higher than that reported elsewhere. In a published paper that includes patients with BC without hereditary criteria, mutation rates of $4.1 \%$ have been reported in non-BRCA1/2 genes. [27]. Studies in families with a high risk of $B C$ have reported a mutation rate of between $4 \%$ and $6.2 \%$ in non-BRCA1/2 genes $[8,28,29]$. Although the series in American populations of high-risk families present data for a remarkably high number of patients, relatively less information is available for the European population, and especially, the Spanish population. Recently, Bonache et al. published a study in 300 high-risk Spanish families in which the non-BRCA1/2 gene mutation rate was $8 \%$ [30]. Although ATM and CHEK2 were the most frequent PVs detected in the HBOC population, the high frequency detected in our series for these genes was striking. In the large series by Couch et al. of 58,798 women with $\mathrm{BC}$ that were referred to hereditary cancer clinics, a mutation rate of $1.73 \%$ for $C H E K 2,1.06 \%$ for $A T M$, and $0.87 \%$ for PALB2 were reported [28]. In a German cohort of $5589 \mathrm{BC}$ index patients, with hereditary high-risk criteria, Hauke et al. found a mutation prevalence of $2.5 \%$ for CHEK2, $1.5 \%$ for ATM, and $1.2 \%$ for PALB2 [31]. The elevated percentage of PVs in ATM and CHEK2 in our study may be because families had a high burden of BC.

The five pathogenic mutations we detected in ATM (two splicing, one frameshift, and two stop codon) caused a loss of function (LoF) of the protein. Of the four PVs detected in CHEK2, three caused a LoF (one frameshift and two stop codon) and the other was a missense mutation. A recent study assessed whether there is a different risk of $\mathrm{BC}$ according to the type of mutation detected and found that for ATM, this risk is higher in variants with LoF than in deleterious missense variants. However, they found no differences for the types of variants in CHEK2 and PALB2 genes. [32] Another recent paper also reported that rare missense variants in CHEK2 were associated with an increased risk of $\mathrm{BC}$, and that this association was independent of the locus [33]. We found a rare missense variant in CHEK2 with discrepancies in the classification guidelines, but with some evidence of pathogenicity reported in the literature and predictive models $[10,11]$.

Of note, we detected no PVs and only one VUS in PALB2, probably because of the small size of our series. Indeed, this gene has been repeatedly identified as mutated in women with $\mathrm{BC}$ and family risk factors. In fact, Thompson et al. found that half the 
risk resulting from mutations in genes other than $B R C A 1 / 2$ was caused by mutations in PALB2 [8]. Regarding ATM and CHEK2, deleterious mutations in these genes were more frequent in estrogen receptor (ER)-positive tumors, while CHEK2 mutations were also frequently found in HER2 positive tumors [13,31,33]. Consistent with these data, all the $\mathrm{BC}$ cases in our series with mutations in one of these two genes were ER-positive.

Both missense TP53 variants identified (c.743G > A, p.Arg248Gln, and c.638G > A, p.Arg213Gln) are listed in the IARC TP53 database [34] and have been reported as dominantnegative PV (in which the mutated p53 protein interferes with the function of the wild type p53 protein) [35]. Some studies have reported that individuals with dominant-negative PV appeared to have more clinically severe phenotypes than individuals with other TP53 PV did [36,37]. None of the two families in our study fulfilled the classic criteria for LiFraumeni syndrome, although they meet the Chompret criteria [38,39]. In addition, the two ICs carrying a TP53 mutation were diagnosed with BC at a very young age and one of them harbored a HER2 amplification. Mutations in TP53 are associated with early-onset $\mathrm{BC}$ and over two-thirds of BCs in women with Li-Fraumeni syndrome have some degree of HER2 amplification [40]. Some authors have proposed that cases of BC in very young women (before 31 years) should be tested for TP53 genes because, in many families, the mutations in this gene would not have been detected via a family history alone [36]. In these cases, the identification of a pathogenic TP53 mutation allows physicians to change the management in young unaffected females carrying this mutation; for example, by suggesting they undergo a risk-reducing bilateral mastectomy [41].

One of the ICs we report here presented a pathogenic mutation in MSH2 in a family with two cases of BC, one case of colon cancer diagnosed at 68 years, and one of gastric cancer diagnosed at 55 years. Although multiple reports have suggested a moderate risk of BC in cases of mismatch repair gene mutations, especially for MSH6 [13], other authors did not observe this relationship [28]. Furthermore, current National Comprehensive Cancer Network guidelines do not advise following patients with Lynch syndrome for BC, but rather recommend management based solely on the family history of $\mathrm{BC}$ [3]. However, the relationship between Lynch syndrome and OC is more robust, although its relative risk has not yet been clearly established; Lu et al. observed that mismatch repair genes confer a moderate risk for OC, with an OR 4.16 [13].

Although BRIP1 is related with a moderate risk for OC and its relationship with $\mathrm{BC}$ is not well established, we found a PV in a family with high-risk features for BC and without any case of identified OC. A similar finding was also reported in another Spanish cohort [30].

One BC IC harbored a novel LoF variant in CASP8. This frameshift variant has not been described previously in ClinVar and was predicted to encode for a non-functional protein in VarSome. CASP8 regulates apoptosis and common variants of this gene (SNPs) have been identified as low penetrance $\mathrm{BC}$ genes through genome-wide analysis in several trials [42-45]. Although little is known about germinal LoF variants in CASP8 in relation to $\mathrm{BC}$ risk, somatic mutations in this gene have been identified as drivers of $B C$ development [46]. Recent studies have proposed that rare LoF variants from low penetrance genes in BC, including CASP8, could be associated with a higher risk of BC than SNPs [47,48]. However, because insufficient data are available, this result will not be used in clinics and a segregation analysis was instead proposed for this family.

Consistently with already published extensive series, which do not consider RAD50, NBN, MLH1, PMS2, or MRE11 relevant factors in BC risk [8,28], we did not identify any PVs in any of these genes. However, RAD51C and RAD51D were related with a moderately increased risk in two large, recently published studies $[33,49]$.

The high percentage of VUS in these moderate-penetrance genes is another recurrent characteristic described in these studies, with reported ranges of $14-36 \%$ [27,31,50]. We found VUS in $22.9 \%$ of our cohort, which is within the range commonly described. VUS should not be used for clinical decision making, but their high percentage is ex- 
pected to decrease with further research over time, in an analogous way to those for the $B R C A 1 / 2$ genes.

One of the advantages of multi-gene panel sequencing is that it allows patients carrying more than one mutation to be detected where these individuals would have previously remained undetected by the sequential study of mutations. Therefore, these tests allow physicians to provide patients with more complete genetic advice [29]. For example, in our work, we detected one patient with two PV, one each in ATM and CHEK2.

The introduction of multigene panels has led to the frequent detection of genes associated with specific cancer syndromes in individuals that do not meet the inclusion criteria usually established by studies [29]. For example, in our series, we detected one IC with a MSH2 mutation whose family did not meet the Amsterdam II or Bethesda criteria for Lynch syndrome. Nonetheless, although this may help detect syndromes that were not detected in single-gene sequencing, many authors have warned that the presentation of cases detected by multigene panel testing may be different from that of cases detected by classic syndromic presentations. For example, Rana et al. found that the average age of presentation of BC in patients with mutations in TP53 detected by a multigene panel was greater than the mean age of those detected by analysis of a single gene [51]. In fact, some authors have warned that in some cases, the detection of these PVs may be an incidental finding not causally related to the family risk of $\mathrm{BC}$, and so these findings should be interpreted with caution, both towards patients and their families. Indeed, Thompson et al. found a similar rate of mutations between a BC population enriched for hereditary cancer features and a cancer-free control population [8].

It is also important to remember that criteria that predict the probability of mutation in non-BRCA1/2 genes are largely unknown and may differ from those that predict mutation probabilities in BRCA1/2 [31]. Current testing guidelines do not adequately account for the full range of clinical presentations described to date as associated with $\mathrm{BC}$, and carriers of clinically actionable variants in genes other than $B R C A 1 / 2$ are likely to still fall outside these guidelines [52]. Recent studies have found no relationship between a younger age at the time of $\mathrm{BC}$ diagnosis and a higher prevalence of PVs in moderate-penetrance genes $[31,50,53]$. Accordingly, we observed no difference in median age between patients with or without PV. Another remaining question is whether a higher family burden of BC cases implies a greater probability of detecting PVs. Our population mainly comprised patients selected because they had a strong family history of BC, which could perhaps partially justify the high rate of mutation detected. However, we did not observe that the detection of a greater number of cases of $\mathrm{BC}$ in the family implied an increased probability of detecting PVs.

Considering all these issues together, although multigene panel testing provides large, pragmatic data sets, at the individual level, this information must be interpreted with caution to avoid providing patients with potentially misleading clinical misinformation that could cause harm [8]. The value of multigene panel testing remains controversial, because there is uncertainty regarding the strength of association between mutations in some genes and the development of cancer (clinical validity) and there is a lack of genetic evidence demonstrating improved outcomes for the individuals tested (clinical utility) [9]. Clinicians must possess robust data with proven utility before using genetic testing involving new $\mathrm{BC}$ risk genes to provide adequate and proportional risk reduction strategies and to avoid the overtreatment of these families [41]. Regarding intervention measures, no scientific evidence on the role of risk-reducing surgeries is yet available, either at the level of the breast or ovary, and some authors have warned of the risk of causing harm to the patient if measures taken for high-penetrance genes are applied in patients carrying mutations in moderate-penetrance genes [8]. In fact, the review by Tung et al. proposes guidelines for monitoring and evaluating surgeries based on the risk of each gene and the existence of a significant family history [9].

In summary, the cohort considered in our work was small compared to the studies with thousands of patients presented in recent years, with the latter allowing much more 
robust conclusions to be drawn. However, given the many questions that remain to be answered in the field of moderate-penetrance genes in HBOC and the fact that these large-scale studies included patients that represented populations different from ours, we suggest that collaborative efforts with population studies from different areas could help researchers to better understand this syndrome. Notwithstanding, working on this 'small patient sample' allowed us to familiarize ourselves with the technique of NGS and validate it. Thus, we recognized genes that we had never previously studied which are now part of our routine clinical practice assessments. In fact, many of these genes have now been incorporated into the service portfolio of the Genetic Counseling Program forming part of the Comunidad Valenciana Cancer Plan. An NGS panel with 40 genes related with hereditary cancer syndromes was developed in our community. From this panel, a subgroup of 13 genes is analyzed in those patients with HBOC syndrome: ATM, BRCA1, BRCA2, BRIP1, CHEK2, EPCAM, MLH1, MHS2, MSH6, NBN, PALB2, RAD51C, and RAD51D. CDH1, NF1, PTEN, STK11 and TP53 genes are analyzed when the family meets clinical criteria for it. All these genes were included in our previous panel here presented.

Supplementary Materials: The following are available online at https: / www.mdpi.com/article / 10.3390/jpm11060548/s1, Table S1: variants of unknown significance (VUS) in the study cohort; Figure S1: quality by base throughout the readings; Figure S2: quality values per read.

Author Contributions: Conceptualization, M.F. and E.M.-D.; methodology, M.F.; software, M.F. and I.d.J.J.; validation, I.d.J.J.; formal analysis, I.d.J.J.; investigation, M.F. and I.d.J.J.; resources, M.F., I.C., A.B.S.-H., A.S., P.R.-A.; data curation, M.F. and I.d.J.J.; writing-original draft preparation, M.F.; writing-review and editing, I.d.J.J. and E.M.-D.; visualization, I.T., I.C., A.B.S.-H., A.S., P.R.-A.; supervision, E.M.-D.; project administration, M.F. and E.M.-D.; funding acquisition, M.F. and E.M.-D. All authors have read and agreed to the published version of the manuscript.

Funding: This research was funded by LeCadó Foundation, grant number PRV00039.

Institutional Review Board Statement: The study was conducted according to the guidelines of the Declaration of Helsinki, and approved by the Ethics Committee of Provincial Hospital of Castellon (FHPCS-P17-01 and 27 April 2017).

Informed Consent Statement: Informed consent was obtained from all subjects involved in the study.

Acknowledgments: The authors acknowledge the Castellon Provincial Hospital Foundation for their statistical and administrative support, the valuable contributions of the INCLIVA Bioinformatics and Biostatistics Unit, and Maria Hannah Ledran for medical writing services.

Conflicts of Interest: The authors declare no conflict of interest. The funders had no role in the design of the study; in the collection, analyses, or interpretation of data; in the writing of the manuscript, or in the decision to publish the results.

\section{References}

1. Ferlay, J.; Colombet, M.; Soerjomataram, I.; Mathers, C.; Parkin, D.M.; Pineros, M.; Znaor, A.; Bray, F. Estimating the global cancer incidence and mortality in 2018: GLOBOCAN sources and methods. Int. J. Cancer 2019, 144, 1941-1953. [CrossRef] [PubMed]

2. Kurian, A.W.; Hare, E.E.; Mills, M.A.; Kingham, K.E.; McPherson, L.; Whittemore, A.S.; McGuire, V.; Ladabaum, U.; Kobayashi, Y.; Lincoln, S.E.; et al. Clinical Evaluation of a Multiple-Gene Sequencing Panel for Hereditary Cancer Risk Assessment. J. Clin. Oncol. 2014, 32, 2001-2009. [CrossRef]

3. Daly, M.B.; Pilarski, R.; Berry, M.P.; Buys, S.S. Genetic/Familial High-Risk Assessment: Breast, Ovarian, and Pancreatic. NCCN Clin. Pract. Guidel. Oncol. 2021, 19, 77-102. [CrossRef]

4. Nielsen, F.C.; Van Overeem Hansen, T.; Sørensen, C.S. Hereditary breast and ovarian cancer: New genes in confined pathways. Nat. Rev. Cancer 2016, 16, 599-612. [CrossRef]

5. Easton, D.F.; Pharoah, P.D.P.; Antoniou, A.C.; Tischkowitz, M.; Tavtigian, S.V.; Nathanson, K.L.; Devilee, P.; Meindl, A.; Couch, F.J.; Southey, M.; et al. Gene-panel sequencing and the prediction of breast-cancer risk. N. Engl. J. Med. 2015, 372, $2243-2257$. [CrossRef]

6. Castéra, L.; French Exome Project Consortium; Harter, V.; Muller, E.; Krieger, S.; Goardon, N.; Ricou, A.; Rousselin, A.; Paimparay, G.; Legros, A.; et al. Landscape of pathogenic variations in a panel of 34 genes and cancer risk estimation from 5131 HBOC families. Genet. Med. 2018, 20, 1677-1686. [CrossRef] 
7. Meiss, A.E.; Thomas, M.; Modesitt, S.C.; Ring, K.L.; Atkins, K.A.; Mills, A.M. Clinicopathologic characterization of breast carcinomas in patients with non-BRCA germline mutations: Results from a single institution's high-risk population. Hum. Pathol. 2018, 82, 20-31. [CrossRef] [PubMed]

8. Thompson, E.R.; Rowley, S.M.; Li, N.; McInerny, S.; Devereux, L.; Wong-Brown, M.W.; Trainer, A.; Mitchell, G.; Scott, R.; James, P.; et al. Panel testing for familial breast cancer: Calibrating the tension between research and clinical care. J. Clin. Oncol. 2016, 34, 1455-1459. [CrossRef] [PubMed]

9. Tung, N.; Domchek, S.M.; Stadler, Z.; Nathanson, K.L.; Couch, F.; Garber, J.E.; Offit, K.; Robson, M.E. Counselling framework for moderate-penetrance cancer-susceptibility mutations. Nat. Rev. Clin. Oncol. 2016, 13, 581. [CrossRef]

10. Kleiblova, P.; Stolarova, L.; Krizova, K.; Lhota, F.; Hojny, J.; Zemankova, P.; Havranek, O.; Vocka, M.; Cerna, M.; Lhotova, K.; et al. Identification of deleterious germline CHEK2 mutations and their association with breast and ovarian cancer. Int. J. Cancer 2019, 145, 1782-1797. [CrossRef] [PubMed]

11. Le Calvez-Kelm, F.; Lesueur, F.; Damiola, F.; Vallée, M.; Voegele, C.; Babikyan, D.; Lesueur, F.; Byrnes, G.B.; Chuang, S.-C.; Forey, N.; et al. Rare, evolutionarily unlikely missense substitutions in CHEK2 contribute to breast cancer susceptibility: Results from a breast cancer family registry case-control mutation-screening study. Breast Cancer Res. 2011, 13, 1-12. [CrossRef]

12. Ma, X.; Zhang, B.; Zheng, W. Genetic variants associated with colorectal cancer risk: Comprehensive research synopsis, metaanalysis, and epidemiological evidence. Lancet Oncol. 2014, 12, 477-488. [CrossRef]

13. Lu, H.M.; Li, S.; Black, M.H.; Lee, S.; Hoiness, R.; Wu, S.; Mu, W.; Huether, R.; Chen, J.; Sridhar, S.; et al. Association of Breast and Ovarian Cancers with Predisposition Genes Identified by Large-Scale Sequencing. JAMA Oncol. 2019, 5, 51-57. [CrossRef] [PubMed]

14. Castéra, L.; Krieger, S.; Rousselin, A.; Legros, A.; Baumann, J.-J.; Bruet, O.; Brault, B.; Fouillet, R.; Goardon, N.; Letac, O.; et al. Next-generation sequencing for the diagnosis of hereditary breast and ovarian cancer using genomic capture targeting multiple candidate genes. Eur. J. Hum. Genet. 2014, 22, 1305-1313. [CrossRef] [PubMed]

15. Levine, A.J.; Momand, J.; Finlay, C.A. The p53 tumour suppressor gene. Nature 1991, 351, 453-456. [CrossRef]

16. Borras, E.; Chang, K.; Pande, M.; Cuddy, A.; Bosch, J.L.; Bannon, S.A.; Mork, M.E.; Rodriguez-Bigas, M.A.; Taggart, M.W.; Lynch, P.M.; et al. In silico systems biology analysis of variants of uncertain significance in lynch syndrome supports the prioritization of functional molecular validation. Cancer Prev. Res. 2017, 10, 580-587. [CrossRef]

17. Barrington, D.A.; Champion, M.L.; Boitano, T.K.L.; Walters-Haygood, C.L.; Farmer, M.B.; Alvarez, R.D.; Estes, J.M.; Leath, C.A. Characteristics of African American women at high-risk for ovarian cancer in the southeast: Results from a Gynecologic Cancer Risk Assessment Clinic. Gynecol Oncol. 2018, 149, 337-340. [CrossRef] [PubMed]

18. García-Pérez, M.A.; Allende, L.M.; Corell, A.; Varela, P.; Moreno, A.A.; Sotoca, A.; Moreno, A.; Paz-Artal, E.; Barreiro, E.; Arnaiz-Villena, A. Novel mutations and defective protein kinase C activation of T-lymphocytes in ataxia telangiectasia. Clin. Exp. Immunol. 2001, 123, 472-480. [CrossRef]

19. Cock-Rada, A.M.; Ossa, C.A.; García, H.I.; Gomez, L.R. A multi-gene panel study in hereditary breast and ovarian cancer in Colombia. Fam. Cancer 2018, 17, 23-30. [CrossRef] [PubMed]

20. Telatar, M.; Wang, Z.; Castellvi-Bel, S.; Tai, L.-Q.; Sheikhavandi, S.; Regueiro, J.; Porras, O.; Gatti, R. A Model for ATM Heterozygote Identification in a Large Population: Four Founder-Effect ATM Mutations Identify Most of Costa Rican Patients with Ataxia Telangiectasia. Mol. Genet. Metab. 1998, 64, 36-43. [CrossRef]

21. Maxwell, K.N.; Wubbenhorst, B.; Andrea, K.D.; Garman, B.; Long, J.M.; Lcgc, M.S.; Zhu, J.; Bradbury, A.R.; Simon, M.S.; DeMichele, A.; et al. Prevalence of mutations in a panel of breast cancer susceptibility genes in BRCA1/2 negative patients with early onset breast cancer. Genet. Med. 2016, 17, 630-638. [CrossRef]

22. Decker, B.; Allen, J.; Luccarini, C.; Pooley, K.A.; Shah, M.; Bolla, M.K.; Wang, Q.; Ahmed, S.; Baynes, C.; Conroy, D.M.; et al. Rare, protein-truncating variants inATM, CHEK2 and PALB2, but not XRCC2, are associated with increased breast cancer risks. J. Med Genet. 2017, 54, 732-741. [CrossRef] [PubMed]

23. Leedom, T.P.; LaDuca, H.; McFarland, R.; Li, S.; Dolinsky, J.S.; Chao, E.C. Breast cancer risk is similar for CHEK2 founder and non-founder mutation carriers. Cancer Genet. 2016, 209, 403-407. [CrossRef]

24. Olivier, M.; Goldgar, D.E.; Sodha, N.; Ohgaki, H.; Kleihues, P.; Hainaut, P.; Eeles, R.A. Li-Fraumeni and related syndromes: Correlation between tumor type, family structure, and TP53 genotype. Cancer Res. 2003, 63, 6643-6650. [PubMed]

25. ClinVar. Available online: https://www.ncbi.nlm.nih.gov/clinvar/ (accessed on 22 December 2020).

26. Nielsen, M.; Morreau, H.; Vasen, H.F.A.; Hes, F.J. MUTYH-associated polyposis (MAP). Crit. Rev. Oncol. 2011, 79, 1-16. [CrossRef]

27. Tung, N.; Lin, N.U.; Kidd, J.; Allen, B.A.; Singh, N.; Wenstrup, R.J.; Hartman, A.-R.; Winer, E.P.; Garber, J.E. Frequency of Germline Mutations in 25 Cancer Susceptibility Genes in a Sequential Series of Patients with Breast Cancer. J. Clin. Oncol. 2016, 34, 1460-1468. [CrossRef]

28. Couch, F.J.; Shimelis, H.; Hu, C.; Hart, S.N.; Polley, E.C.; Na, J.; Hallberg, E.; Moore, R.; Thomas, A.; Lilyquist, J.; et al. Associations between Cancer Predisposition Testing Panel Genes and Breast Cancer. JAMA Oncol. 2017, 3, 1190-1196. [CrossRef]

29. Eliade, M.; Skrzypski, J.; Baurand, A.; Jacquot, C.; Bertolone, G.; Loustalot, C.; Coutant, C.; Guy, F.; Fumoleau, P.; Duffourd, Y.; et al. The transfer of multigene panel testing for hereditary breast and ovarian cancer to healthcare: What are the implications for the management of patients and families? Oncotarget 2016, 8, 1957-1971. [CrossRef] 
30. Bonache, S.; Esteban, I.; Moles-Fernández, A.; Tenés, A.; Duran-Lozano, L.; Montalban, G.; Bach, V.; Carrasco, E.; Gadea, N.; López-Fernández, A.; et al. Multigene panel testing beyond BRCA1/2 in breast/ovarian cancer Spanish families and clinical actionability of findings. J. Cancer Res. Clin. Oncol. 2018, 144, 2495-2513. [CrossRef]

31. Hauke, J.; Horvath, J.; Groß, E.; Gehrig, A.; Honisch, E.; Hackmann, K.; Schmidt, G.; Arnold, N.; Faust, U.; Sutter, C.; et al. Gene panel testing of 5589 BRCA1/2-negative index patients with breast cancer in a routine diagnostic setting: Results of the German Consortium for Hereditary Breast and Ovarian Cancer. Cancer Med. 2018, 7, 1349-1358. [CrossRef] [PubMed]

32. Girard, E.; Eon-Marchais, S.; Olaso, R.; Renault, A.; Damiola, F.; Dondon, M.; Barjhoux, L.; Goidin, D.; Meyer, V.; Le Gal, D.; et al Familial breast cancer and DNA repair genes: Insights into known and novel susceptibility genes from the GENESIS study, and implications for multigene panel testing. Int. J. Cancer 2019, 144, 1962-1974. [CrossRef]

33. Dorling, L.; Carvalho, S.; Allen, J.; González-Neira, A.; Luccarini, C.; Wahlström, C.; Pooley, K.A.; Parsons, M.T.; Fortuno, C.; Wang, Q.; et al. Breast Cancer Risk Genes-Association Analysis in More than 113,000 Women. N. Engl. J. Med. 2021, 384, 428-439.

34. p53IARC. Available online: https:/ / p53.iarc.fr/ (accessed on 16 February 2021).

35. Schneider, K.; Zelley, K.; Nichols, K.E.; Garber, J. Li-Fraumeni Syndrome. In Gene Reviews. Available online: https:/ /www.ncbi. nlm.nih.gov/books/NBK1311/?report=classic (accessed on 17 March 2021).

36. Bougeard, G.; Renaux-Petel, M.; Flaman, J.-M.; Charbonnier, C.; Fermey, P.; Belotti, M.; Gauthier-Villars, M.; Stoppa-Lyonnet, D.; Consolino, E.; Brugières, L.; et al. Revisiting Li-Fraumeni Syndrome From TP53 Mutation Carriers. J. Clin. Oncol. 2015, 33, 2345-2352. [CrossRef]

37. Zerdoumi, Y.; Lanos, R.; Raad, S.; Flaman, J.M.; Bougeard, G.; Frebourg, T.; Tournier, I. Germline TP53 mutations result into a constitutive defect of p53 DNA binding and transcriptional response to DNA damage. Hum. Mol. Genet. 2017, 26, 2591-2602. [CrossRef] [PubMed]

38. Li, F.P.; Fraumeni, J.F.; Mulvihill, J.J.; Blattner, W.A.; Dreyfus, M.G.; Tucker, M.A.; Miller, R.W. A cancer family syndrome in twenty-four kindreds. Cancer Res. 1988, 48, 5358-5362. [PubMed]

39. Tinat, J.; Bougeard, G.; Baert-Desurmont, S.; Vasseur, S.; Martin, C.; Bouvignies, E.; Caron, O.; Paillerets, B.B.-D.; Berthet, P.; Dugast, C.; et al. 2009 Version of the Chompret Criteria for Li Fraumeni Syndrome. J. Clin. Oncol. 2009, 27, e108-e109. [CrossRef] [PubMed]

40. Rath, M.G.; Masciari, S.; Gelman, R.; Miron, A.; Miron, P.; Foley, K.; Richardson, A.L.; Krop, I.E.; Verselis, S.J.; Dillon, D.A.; et al. Prevalence of germline TP53 mutations in HER2+ breast cancer patients. Breast Cancer Res. Treat. 2013, 139, 193-198. [CrossRef]

41. Li, J.; Meeks, H.; Feng, B.-J.; Healey, S.; Thorne, H.; Makunin, I.; Ellis, J.; Campbell, I.; Southey, M.; Mitchell, G.; et al. Targeted massively parallel sequencing of a panel of putative breast cancer susceptibility genes in a large cohort of multiple-case breast and ovarian cancer families. J. Med Genet. 2016, 53, 34-42. [CrossRef]

42. Lin, W.-Y.; Camp, N.J.; Ghoussaini, M.; Beesley, J.; Michailidou, K.; Hopper, J.L.; Apicella, C.; Southey, M.C.; Stone, J.; Schmidt, M.K.; et al. Identification and characterization of novel associations in the CASP8/ALS2CR12 region on chromosome 2 with breast cancer risk. Hum. Mol. Genet. 2015, 24, 285-298. [CrossRef]

43. Camp, N.J.; Parry, M.; Knight, S.; Abo, R.; Elliott, G.; Rigas, S.H.; Balasubramanian, S.P.; Reed, M.; McBurney, H.; Latif, A.; et al. Fine-Mapping CASP8 Risk Variants in Breast Cancer. Cancer Epidemiol. Biomark. Prev. 2012, 21, 176-181. [CrossRef]

44. Michailidou, K.; Beesley, J.; Lindstrom, S.; Canisius, S.; Dennis, J.; Lush, M.J.; Maranian, M.J.; Bolla, M.K.; Wang, Q.; Shah, M.; et al. Genome-wide association analysis of more than 120,000 individuals identifies 15 new susceptibility loci for breast cancer. Nat. Genet. 2015, 47, 373-380. [CrossRef]

45. Yang, Y.; Shu, X.; Shu, X.-O.; Bolla, M.K.; Kweon, S.-S.; Cai, Q.; Michailidou, K.; Wang, Q.; Dennis, J.; Park, B.; et al. Re-evaluating genetic variants identified in candidate gene studies of breast cancer risk using data from nearly 280,000 women of Asian and European ancestry. EBioMedicine 2019, 48, 203-211. [CrossRef]

46. Stephens, P.J.; Tarpey, P.S.; Davies, H.; Van Loo, P.; Greenman, C.; Wedge, D.C.; Nik-Zainal, S.; Martin, S.; Varela, I.; Bignell, G.R.; et al. The landscape of cancer genes and mutational processes in breast cancer. Nature 2012, 486, 400-404. [CrossRef]

47. Li, N.; Rowley, S.M.; Thompson, E.R.; McInerny, S.; Devereux, L.; Amarasinghe, K.C.; Zethoven, M.; Lupat, R.; Goode, D.; Li, J.; et al. Evaluating the breast cancer predisposition role of rare variants in genes associated with low-penetrance breast cancer risk SNPs. Breast Cancer Res. 2018, 20, 3. [CrossRef]

48. Aloraifi, F.; McDevitt, T.; Martiniano, R.; McGreevy, J.; McLaughlin, R.; Egan, C.M.; Cody, N.; Meany, M.; Kenny, E.; Green, A.J.; et al. Detection of novel germline mutations for breast cancer in non-BRCA1/2 families. FEBS J. 2015, 282, 3424-3437. [CrossRef] [PubMed]

49. Hu, C.; Hart, S.N.; Gnanaolivu, R.; Huang, H.; Lee, K.Y.; Na, J.; Gao, C.; Lilyquist, J.; Yadav, S.; Boddicker, N.J.; et al. A PopulationBased Study of Genes Previously Implicated in Breast Cancer. N. Engl. J. Med. 2021, 384, 440-451. [CrossRef]

50. Buys, S.S.; Sandbach, J.F.; Gammon, A.; Patel, G.; Kidd, J.; Brown, K.L.; Sharma, L.; Saam, J.; Lancaster, J.; Daly, M.B. A study of over 35,000 women with breast cancer tested with a 25-gene panel of hereditary cancer genes. Cancer 2017, 123, 1721-1730. [CrossRef]

51. Rana, H.Q.; Gelman, R.; LaDuca, H.; McFarland, R.; Dalton, E.; Thompson, J.; Speare, V.; Dolinsky, J.S.; Chao, E.C.; Garber, J.E. Differences in TP53 Mutation Carrier Phenotypes Emerge from Panel-Based Testing. J. Natl. Cancer Inst. 2018, 110, 863-870. [CrossRef] [PubMed] 
52. Beitsch, P.D.; Whitworth, P.W.; Hughes, K.; Patel, R.; Rosen, B.; Compagnoni, G.; Baron, P.; Simmons, R.; Smith, L.A.; Grady, I.; et al. Underdiagnosis of hereditary breast cancer: Are genetic testing guidelines a tool or an obstacle? J. Clin. Oncol. 2019, 37, 453-460. [CrossRef] [PubMed]

53. Young, S.R.; Pilarski, R.T.; Donenberg, T.; Shapiro, C.; Hammond, L.S.; Miller, J.; Brooks, K.A.; Cohen, S.; Tenenholz, B.; DeSai, D.; et al. The prevalence of BRCA1 mutations among young women with triple-negative breast cancer. BMC Cancer $2009,9,86$. [CrossRef] [PubMed] 